\title{
Zadania polonistów w szkole pomyślanej na nowo. Jak uczyć uczenia się
}

\author{
Tasks of Polish language teachers in a re-invented \\ school. How to teach students to learn
}

\author{
Kinga Białek
Szkoła Edukacji Polsko-Amerykańskiej Fundacji
Wolności i Uniwersytetu Warszawskiego \\ ORCID: 0000-0001-5164-9502
}

\begin{abstract}
The situation of the pandemic and the March lockdown allows us to look at education in Poland as an element of a complex system of influences and heterotopias, in line with Foucault's concept. Realizing the importance of a well-planned educational policy in the context of social needs will allow teachers to set goals more accurately and effectively. The pandemic has exacerbated the social inequalities existing in Poland which have an impact on the effectiveness of education. Education focused on empowerment and, implemented by strengthening cognitive autonomy in the lessons of critical reading, may be an answer from the field of the Polish studies. The text also proposes lesson activities based on the procedural reading method.
\end{abstract}

Key words: cognitive autonomy, critical literacy, subjectification, procedural reading

Streszczenie: Sytuacja pandemii i marcowego lockdownu pozwala spojrzeć na edukację w Polsce jako na element złożonego systemu wpływów i heterotopię, zgodnie z koncepcją Foucaulta. Uświadomienie sobie ważności dobrze zaplanowanej polityki edukacyjnej w kontekście potrzeb społecznych pozwoli celniej i skutecznej postawić cele działalności nauczycieli. Pandemia wzmocniła istniejące w Polsce nierówności społeczne, które mają wpływ na efektywność kształcenia. Odpowiedzią na gruncie polonistyki szkolnej może być kształcenie nastawione na upodmiotowienie, realizowane przez wzmacnianie autonomii poznawczej na lekcjach krytycznego czytania. W tekście zaproponowano także propozycję działań lekcyjnych opartych na metodzie czytania proceduralnego.

Słowa kluczowe: autonomia poznawcza, czytanie proceduralne, krytyczne czytanie, upodmiotowienie

\section{Czym jest i czym być powinna szkoła w dobie kryzysu?}

W marcu 2020 roku wszyscy doświadczyliśmy nagłego i niespodziewanego kryzysu w postaci pandemii Covid 19. Doświadczenie to, pierwsze od wielu lat wydarzenie o skali globalnej, wstrząsnęło nie tylko codziennym 
życiem milionów ludzi, ale także sprawiło, że z coraz większym niepokojem patrzymy w przyszłość. Marcowe zamknięcie szkół było jednym z wielu skutków pandemii, która okazała się nie tylko chorobą ciała, ale także schorzeniem atakującym wszystkie sfery życia społecznego i funkcjonowania państwa.

W tym kontekście warto spojrzeć na edukację w Polsce, także edukację polonistyczną, jako na element złożonego systemu wpływów, oczekiwań i oddziaływań. Posłużę się w tym celu modelem heterotopii Michela Foucaulta (por. Archacka, 2016). W eseju francuskiego filozofa czytamy:

Są też prawdopodobnie w każdej kulturze, w każdej cywilizacji, miejsca (lieux) rzeczywiste - miejsca, które wyznaczane są wraz z tworzeniem się społeczeństwa, które są czymś w rodzaju kontr-miejsc (contre-emplacements), rodzajem efektywnie odgrywanej utopii, w której wszystkie inne rzeczywiste miejsca (emplacements), jakie można znaleźć w ramach kultury, są jednocześnie reprezentowane, kontestowane i odwracane. Miejsca (lieux) tego typu są poza wszystkimi miejscami, chociaż nie jest wykluczona możliwość wskazania ich lokalizacji. Ponieważ miejsca (lieux) te są absolutnie odmienne od wszystkich miejsc (emplacements), które odzwierciedlają i o których mówią, nazwę je w przeciwieństwie do utopii, heterotopiami (Foucault 2005, 120).

Szkoła wydaje się miejscem szczególnym na mapie współczesnych przestrzeni kulturowych. Doświadczenie szkoły od ponad stu lat jednoczy Polki i Polaków niezależnie od ich statusu materialnego czy społecznego, potencjału kulturowego, a nawet - języka codziennej komunikacji. W szkole ludzie, odgrywający poza nią wiele ról społecznych i kulturowych, zostają zrównani do roli uczniów niejako pod przymusem. Muszą bowiem dostosować się do panującej w niej hierarchii oraz obowiązujących formalnych i nieformalnych zasad. Szkoła jest przestrzenią wyłączoną, w której zawiesza się zewnętrzne normy i reguły postępowania, zastępując je wewnętrznymi, często nieczytelnymi dla osób spoza niej. Z drugiej strony - doświadczenie uczestnictwa w edukacji jest doświadczeniem powszechnym: wszyscy jesteśmy lub byliśmy uczniami. Szkoła to zatem przestrzeń dobrze obeznana, jak i obca.

Jest to także przestrzeń związana z konkretnym czasem (heterochronia), zarówno jako miejsce skupiające ludzi na określonym etapie życia i rozwoju, jak i miejsce, w którym bieg czasu wyznaczony jest przez inne jednostki niż te obowiązujące na zewnątrz (jednostki lekcyjne).

Warto również zwrócić uwagę na wielowymiarową i wielopoziomową strukturą szkoły. Z jednej strony ta wielopoziomowość dotyczy relacji międzyludzkich. Uczniowie i uczennice łączą się w wyznaczone grupy (klasy), często zupełnie niezależnie od ich woli. W tych grupach rozgrywa się większość ich życia, od dynamiki w tej grupie zależy ich komfort, często jest to jedyna znacząca rówieśnicza grupa społeczna, w jakiej przebywają. Środowisko to, zasadniczo inne od środowiska rodzinnego, rządzi się swoistymi prawami i zasadami oraz kreuje właściwą sobie (formalną i nieformalną) hierarchię. 
Nieciągła struktura szkoły objawia się także w innej, typowej sytuacji. Wraz z przejściem uczniów z sali do sali (a w dobie pandemii raczej: wraz z wejściem kolejnych nauczycieli do sali) zmienia się nie tylko treść i materiał omawiany na lekcji. Zmieniają się także zakładane sposoby komunikacji, język, strategie uczenia się i światy, które poznajemy. Każda lekcja to „drzwi” do zupełnie innego mikrokosmosu, a często te mikrokosmosy nawet ze sobą nie sąsiadują. Mówiąc mniej metaforycznie: oczekujemy, że podczas lekcji biologii uczeń stanie się na 45 minut biologiem, podczas lekcji języka polskiego przedzierzgnie się w humanistę, a po ostatnim dzwonku powróci do swojej „właściwej” tożsamości, niezależnej od tego, czym zajmował się podczas zajęć. Dodatkowo, cechą wyróżniającą szkołę jako miejsce odrębne jest złożony system kontroli, nie tylko efektów kształcenia (innych na każdym przedmiocie), ale także sposobów zachowania (wspólnych dla grupy klasowej lub całej społeczności szkolnej).

Powyższa analiza przed pandemią miałaby zapewne tylko walor ćwiczenia intelektualnego. Marcowy lockdown sprawił jednak, że ta zamknięta i wyodrębniona przestrzeń „wylała się” poza wyznaczone wcześniej ramy - szkoła „wyszła ze szkoły” i zderzyła się z innymi przestrzeniami, np. domem rodzinnym, w rezultacie tworząc potrzebę przedefiniowania faktycznej, społecznej roli szkoły. Szkoła de facto przestała być heterotopią. Należy zatem mocniej niż kiedykolwiek „otwierać” szkołę na rzeczywistość pozaszkolną.

\section{Szkoła nierównych szans}

W tej sytuacji ujawniła się także inna charakterystyka szkoły, omawiana tym razem z perspektywy nauk społecznych, jako systemu złożonego. Po pierwsze, szkoła jest przestrzenią ścierania się oczekiwań. W społeczeństwach kręgu demokracji liberalnej, w których miarą społecznego dobrobytu jest rozwój jednostek, szkoła ma za zadanie szansę tego dobrobytu zapewnić. Sposobem realizacji takiego zadania byłoby nastawienie szkoły i jej programu na potrzeby rynku pracy i stopniowe odchodzenie od takich celów, które nie byłyby związane z potrzebami gospodarczymi. Z drugiej strony - coraz więcej mówi się o tym, jakoby stopniowe odrzucanie idei demokracji w wielu państwach i społeczeństwach miało swoje źródło w niedostatkach edukacji i wychowania wyniesionych ze szkoły. Pisze o tym Edwin Bendyk, nazywając to zjawisko „liberalnym błędem”:

Polega on na przekonaniu, że powodem odrzucenia liberalnej demokracji i liberalizmu jako ramy organizującej relacje społeczne są deficyty tkwiące w jednostkach tworzących społeczeństwo. Na skutek błędów wychowawczych, niedostatków edukacyjnych, braku kontaktu ze sztuką i kulturą nie wszyscy stali się pełnymi, samosterownymi osobami, zdolnymi do racjonalnej analizy faktów i podejmowania adekwatnych, racjonalnych decyzji (Bendyk 2020, 94-95).

Szkoła zatem ma spełniać różne i nie do końca zbieżne oczekiwania: przygotować idealnych pracowników oraz odbiorców kultury, członków hierarchicznych struktur oraz samodzielnych intelektualnie indywidualistów. 
Po drugie, szkoła jest przestrzenią ścierania się potrzeb. Uczniowie, którzy mają zrealizować jedną wspólną podstawę programową, pochodzą ze środowisk o zróżnicowanym poziomie potencjału kulturowego, społecznego i ekonomicznego. Ma to niewątpliwie wpływ na efektywność kształcenia, jednak dokumenty programowe nie uwzględniają tego problemu. Szkoła nie odpowiada na nie, konserwując istniejący poza nią system nierówności i odrzucając możliwości modelowania przyszłych relacji społecznych. Tak właśnie była postrzegana w miesiącach edukacji zdalnej, o czym rodzice i eksperci edukacyjni informowali w mediach. Podobny wydźwięk miały wypowiedzi gości zaproszonych na debatę online „Epidemia nierówności w edukacji" organizowaną przez forum Idei Fundacji Batorego: Anny Blumsztajn, Małgorzaty Sikorskiej, Przemysława Staronia i Marty Zahorskiej (https://www.youtube.com/watch?v=F438r7XgbGE, dostęp: 7.10.2020). W kontekście pandemii należy o tym szczególnie pamiętać, ponieważ różnice w dostępie do edukacji ujawniły się ze zdwojoną mocą. Jeżeliby potraktować ostatni semestr roku szkolnego 2019/2020 jako sytuacje diagnostyczną, można by spróbować nazwać różne problemy systemu edukacji, zaplanować sposoby ich rozwiązywania, aby w rezultacie stworzyć szkołę pomyślaną na nowo. Taką, która nie kapituluje wobec wyzwań i kryzysów, ale aktywnie wpływa na jakość życia społecznego w przyszłości.

\section{Diagnoza. Jakie trudności polskiej szkoły ujawniła sytuacja pandemii?}

W ostatnich latach przez fora ekonomiczne przetoczyła się burza dotycząca sprzecznych sygnałów na temat nierówności ekonomicznych w Polsce. Z jednej strony poziom wskaźnika Giniego obliczanego na podstawie danych GUS, od lat uznawany jest za zadowalający, z drugiej - od 2017 roku ukazały się dwa duże opracowania potwierdzające zwiększenie poziomu nierówności w naszym kraju. W raporcie How Unequal Is Europe? Evidence from Distributional National Accounts, 1980-2017 opracowanym w ramach projektu World Inequality Database, przeanalizowano przemiany ekonomiczne w krajach Europy, w tym Europy Wschodniej, która od 1990 roku jest w trakcie przemian ustrojowych. Autorzy raportu konkludują, odnosząc się do sytuacji w Polsce:

Poland is the country where income disparities rose most, in part because they continued to rise in the 2000s and 2010s while they more or less stabilized in the rest of the region. In 2017, top $10 \%$ Polish earners received $40 \%$ of national income, more than any of their counterparts in other European countries (Blanchet $i$ in. 2019, 32).

[Polska jest krajem, w którym nierówności dochodowe rosły najbardziej, po części dlatego, że wzrastały w pierwszej i drugiej dekadzie XXI wieku, podczas gdy w innych częściach regionu były mniej lub bardziej ustabilizowane. W 2017 roku, górne 10\% zarabiających w Polsce otrzymywało 40\% dochodu narodowego, więcej niż ich odpowiednicy w innych krajach europejskich].

Do podobnych wniosków dochodzą autorzy innego ważnego opracowania, Inequality in Poland: Estimating the whole distribution by g-percentile, 
1983-2015, wskazując dodatkowo, że kierowanie się tylko wskaźnikiem Giniego w opisie nierówności ekonomicznych prowadzi do zaburzonego obrazu faktycznych trudności Polski (por. Bukowski, Novokmet 2019).

Wpływ nierówności ekonomicznych na jakość i efektywność kształcenia jest dobrze opisany. Autorzy opublikowanego kilka lat temu opracowania Duch równości wykazują bezpośredni wpływ nierówności między innymi na takie dziedziny życia, jak zdrowie fizyczne i psychiczne, uzależnienia, aktywność społeczna i obywatelska, a także wyniki nauczania (por. Pickett, Wilkinson 2011, Atkinson 2017).

Te ostatnie można zmierzyć, analizując wyniki międzynarodowych badań edukacyjnych. Takim badaniem jest niewątpliwie PISA, mierząca poziom umiejętności uczniów w zakresie nauk przyrodniczych, czytania i matematyki. Warto zatrzymać się przy rezultatach ostatniej edycji badania z 2018 roku. Chociaż ogólny wynik wskazuje stałą tendencję wzrostową i zadowalające osiągnięcia na skrajnych krańcach spektrum, to jednak nie wystarczy, by zarzucić programowe działania zmniejszające poziom nierówności edukacyjnych. Wciąż miara sukcesu edukacyjnego jest wprost skorelowana ze wskaźnikami statusu społeczno-ekonomicznego, co potwierdzają autorzy raportu:

Status społeczno-ekonomiczny rodziny ma znaczący wpływ na wyniki ucznia (różnice między średnimi dla górnej i dolnej ćwiartki we wszystkich edycjach i dziedzinach są bardzo wyraźne - przy wartościach rzędu 80-90 punktów zwykle odpowiadają mniej więcej jednemu odchyleniu standardowemu wyniku), jego wpływ się nie zwiększa. (Ostrowska, Sitek 2020, s. 223.).

Było to szczególnie widoczne $\mathrm{w}$ czasie pandemii, o czym alarmowali nie tylko nauczyciele i dyrektorzy szkół, ale także media i organy władz oświatowych.

W tej sytuacji okazało się, jak bardzo utrwalone i zmitologizowane przekonania na temat szkoły wymagają rekonstrukcji. Pierwszym z nich było przekonanie o tym, że w Polsce edukacja jest dostępna dla wszystkich uczniów w tym samym stopniu. O ile istotnie znakomita większość uczniów objęta jest tą samą podstawą programową, o tyle jakość jej realizowania nie jest taka sama dla wszystkich. Nie mam na myśli tylko i wyłącznie różnic indywidualnych w jakości pracy poszczególnych nauczycieli, ale przede wszystkim różnice w sposobach przyswajania i utrwalania wiedzy i umiejętności przez uczniów, a także postawy wobec nauki i uczenia się przez nich prezentowane. Pandemia ujawniła, że problemem polskiej szkoły są nie tylko nierówności widoczne i łatwo mierzalne, ale także te ukryte, związane z kapitałem społecznym i kulturowym. W konsekwencji możemy mówić o grupach uczniów, którym nie udaje się zapewnić dostępu do edukacji na zadowalającym poziomie.

Nierówności powstałe na tym tle dość szybko udało się zdiagnozować w czasie lockdownu. Paulina Sobiesiak-Penszko, Filip Pazderski i Bartłomiej Walczak na zlecenie Fundacji Orange zrealizowali badanie wśród 646 
dyrektorów szkółpodstawowychiśrednich na tereniecałego kraju (Sobiesiak-Penszko i in., 2020). W badaniu zebrano stosowane w różnych szkołach strategie radzenia sobie z sytuacją nauczania zdalnego, ale także zgłaszane przez dyrektorów problemy i trudności w realizowaniu zadań w tym czasie. Oprócz oczywistych trudności wynikających z różnic poziomu zamożności uczniów (81\% dyrektorów zgłaszała, że barierą w edukacji zdalnej jest brak dostępu uczniów do urządzeń, a 41\% wskazywało trudność w dostępie do Internetu), zastanawiający był odsetek dyrektorów upatrujących przyczyn niepowodzeń w edukacji zdalnej w relacjach panujących w domach uczniów. Aż 70\% dyrektorów szkół podstawowych wskazywało, że problemem jest brak czasu rodziców, którzy mieliby wspierać swoje dzieci w uczeniu się. Dodatkowo, autorzy badania wymieniają także inne przyczyny porażek związane z działaniami rodziców: brak umiejętności koordynowania pracy dzieci, trudność w mobilizowaniu dzieci do pracy lub nieradzenie sobie w sytuacji utraty pracy lub środków do życia.

Na tę właśnie trudność zwracali uwagę nauczyciele przebadani w ramach projektu Uczenie (się) w czasie epidemii realizowanego w Szkole Edukacji Polsko-Amerykańskiej Fundacji Wolności i Uniwersytetu Warszawskiego. Marta Wąsowska i Bartłomiej Walczak przeprowadzili w niej ankietę online w dwóch turach: 9-21 kwietnia 2020 (uzyskując 145 odpowiedzi) oraz 10-27 maja 2020 (uzyskując 98 odpowiedzi). Sprawdzali, w jaki sposób zmieniają się postawy nauczycieli wobec edukacji zdalnej. Nauczyciele biorący udział w badaniu potwierdzali doświadczenia innych grup nauczycielskich: obciążenie pracą, trudność w utrzymaniu kontaktu z uczniami i skupieniu ich uwagi na zadaniu, problemy z zastosowaniem nowych narzędzi. Moje zainteresowanie wzbudziła jednak grupa odpowiedzi odnoszących się do zróżnicowania wśród uczniów (13\%) i ich niedostatecznej samodzielności (12\%). W tej pierwszej grupie odpowiedzi pojawiły się komentarze, które przytaczam poniżej (pisownia oryginalna):

- Nauczanie on line niestety powiększa dystans między uczniami biednymi i bogatymi. Ciągle o tym myślę. Bardzo trudno z uczniami o tym rozmawiać, trudno od nich uzyskać taką wiedzę.

- [Wyzwaniem jest] równy dostęp do internetu ,

- Nie wszyscy mają warunki domowe do tego, aby takie lekcje prowadzić czy w nich uczestniczyć. Prowadząc nauczanie online, nie biorąc pod uwagę tego faktu, tworzą większe nierówności społeczne. Wielu uczniów pozostaje bez wsparcia nie tylko edukacyjnego, ale przede wszystkim bez wsparcia psychologicznego.

Szczególnie ważny jest dla mnie pierwszy głos, mówiący o niebezpieczeństwie pogłębiania się różnic w sytuacji nauczania zdalnego.

Z kolei w grupie nauczycieli piszących o trudności związanej z brakiem samodzielności wśród uczniów pojawiły się takie głosy (pisownia oryginalna):

- Brak umiejętności organizacji pracy po stronie uczniów i trudności z dostosowaniem się do nowych warunków. 
- Uczeń musi sam mobilizować się do pracy, organizować sobie czas.

- Wdrażanie uczniów do samokształcenia i obowiązkowości.

- Przejęcie odpowiedzialności przez ucznia / rodzica ucznia za proces edukacyjny.

O ile nierówności ekonomiczne, związane z dostępem do sprzętu elektronicznego, można rozwiązać dość łatwo, o tyle nierówności społeczne, związane ze wsparciem rodziców w procesie uczenia się czy z dostępem do źródeł wiedzy wysokiej jakości lub umiejętnością korzystania z nich, wymagają dużo bardziej złożonych działań. Zwłaszcza że skala konsekwencji wynikających z nierównego dostępu do edukacji zdalnej nie jest jeszcze dobrze znana.

Materiału do porównań może dostarczyć badanie amerykańskie, wykonane w pracowni McKinsey \& Company w czerwcu 2020 roku (McKinsey 2020). Badacze zastanawiali się nad wpływem edukacji zdalnej na funkcjonowanie grup wcześniej rozpoznanych jako szczególnie wrażliwe, czyli low-income, black, and Hispanic students [uczniowie afroamerykańscy i latynoscy z rodzin o niskim dochodzie]. Biorąc pod uwagę dane dotyczące tego, w jaki sposób uczniowie ci korzystają z lekcji online (60\% uczniów z grupy o niskim dochodzie regularnie się loguje na zajęcia, podczas gdy średnio uczniowie z grupy o wysokim dochodzie logują się na $90 \%$ lekcji), analitycy opracowali model „strat edukacyjnych” [learning loss] wyliczanych w miesiącach. W czerwcu 2020 nie było wiadomo, kiedy szkoły zaczną funkcjonować, więc do wyliczeń przyjęto, że powrót do szkół nastąpi w styczniu 2021. W takim wypadku straty edukacyjne dla uczniów afroamerykańskich to 10,3 miesiąca, dla uczniów latynoskich to 9,2 miesiąca (przy średniej stracie 7 miesięcy dla wszystkich uczniów), co może skutkować nawet 20-procentową różnicą wyników edukacyjnych w tych grupach, a także zwiększeniem prawdopodobieństwa przedwczesnego przerwania edukacji na poziomie średnim. Pogłębiająca się przepaść edukacyjna, zdaniem badaczy, ma swoje konsekwencje nie tylko społeczne, ale także ekonomiczne. Opisuje to następujący fragment raportu:

we estimate that the average K-12 student in the United States could lose $\$ 61,000$ to $\$ 82,000$ in lifetime earnings (in constant 2020 dollars), or the equivalent of a year of full-time work, solely as a result of COVID-19-related learning losses. These costs are significant-and worse for black and Hispanic Americans. While we estimate that white students would earn $\$ 1,348$ a year less (a 1.6 percent reduction) over a 40-year working life, the figure is $\$ 2,186$ a year (a 3.3 percent reduction) for black students and \$1,809 (3.0 percent) for Hispanic ones.

This translates into an estimated impact of $\$ 110$ billion annual earnings across the entire current K-12 cohort. (...). This is not just an economic issue. Multiple studies have linked greater educational attainment to improved health, reduced crime and incarceration levels, and increased political participation (McKinsey 2020).

[szacujemy, że przeciętny uczeń z klas 0-12 w Stanach Zjednoczonych może stracić od 61000 do 820000 \& zarobków całego życia (w dolarach o dzisiejszej wartości) lub równowartość rocznego dochodu z pracy na pełen etat, tylko jako konsekwencję strat wynikających z Covid-19. Te koszty są znaczące - i wyższe dla uczniów afroamerykańskich i latynoskich. Szacujemy, że biali uczniowie zarobią o 1348\$ mniej rocznie 
(spadek o 1,6\%) w ciągu 40-letniego okresu pracy, podczas gdy ta liczba to $2186 \$$ rocznie dla Afroamerykanów (spadek o 3,3\%) i 1809\$ dla Latynosów (spadek o 3\%). To przekłada się na skumulowaną stratę 110 miliardów dolarów rocznego dochodu dla całej kohorty uczniów klas 0-12. (...) To nie jest tylko zagadnienie ekonomiczne. Wiele badań łączy osiągnięcia edukacyjne z lepszym zdrowiem, zmniejszonymi poziomami przestępczości i osadzenia w więzieniach oraz zwiększonego poziomu partycypacji politycznej.]

W Polsce, w październiku 2020, nie mamy jeszcze takich badań. Możemy tylko przypuszczać, że społeczne i ekonomiczne koszty, jakie poniosą osoby z grup najmniej uprzywilejowanych, będą ogromne. Warto, podobnie jak to czynią badacze amerykańscy, traktować działania służące wyrównywaniu szans edukacyjnych jako inwestycję w lepszą przyszłość całego społeczeństwa.

Wnioski, jakie należałoby sformułować na podstawie nawet tej pobieżnej obserwacji szkoły po epidemii, dotyczą przede wszystkim wzmocnienia tych działań szkoły, które pozwolą jej stać się przestrzenią zmiany społecznej, a nie konserwowania status quo, i które przybliżą ją do faktycznie zdiagnozowanych problemów społeczeństwa w kryzysie, a nie do powtarzania tych samych, nieaktualnych diagnoz. Aby tak się stało, szkoła musi być instytucją świadomą siebie i otaczającego świata oraz instytucją aktywną, kształtującą ten świat.

\section{Szkoła jako przestrzeń upodmiotowienia}

„Szkoła pomyślana na nowo” nie jest więc instytucją, która ma działać reaktywnie, choć jej działania powinny opierać się na dobrej i dogłębnej diagnozie, która obejmie złożony system wpływów i oczekiwań, które w szkole się zbiegają. W tym kontekście edukacja humanistyczna (lub neohumanistyczna, jak przyjęło się ją nazywać) pełni kluczową rolę.

Żyjemy w czasach kryzysu lub nawet: kryzysów. Coraz więcej zjawisk otaczającej nas rzeczywistości wymaga działań, ale także przyjęcia określonych postaw. Od zawsze humanistyczna refleksja wspierała nas właśnie w rekonstruowaniu znaczenia w chaosie zdarzeń. Jak napisał Yuval Noah Harari, historyk z Uniwersytetu Hebrajskiego w Jerozolimie: „Jest to podstawowe przykazanie, jakie daje nam humanizm: twórzcie sens dla pozbawionego sensu świata" (Harari 2018, 281). Poczucie utraty sensu i niepewności towarzyszy nam od lat, ale sytuacja pandemii to poczucie wzmogła i wymusiła na nas jeśli nie działania, to na pewno namysł. Jak na to wyzwanie powinna odpowiedzieć szkoła?

Zgodnie z postulatami współczesnych filozofów podkreślających wartość humanistyki w świecie opanowanym przez technologie, należy wspierać rozwój nie tylko samodzielnego i krytycznego myślenia uczniów i uczennic, ale także (a może przede wszystkim) budowanie ich refleksji poznawczo-etycznej związanej z gotowością do współistnienia w nowoczesnym społeczeństwie. 
Do tej pory jako państwo wspieraliśmy system, w którym cele powszechnej edukacji były dyktowane przez potrzeby rynku (w tym rynku pracy). Dziś wiemy, że tak definiowane cele nie wystarczają do tego, by szkoła w pełni wyposażała młodych ludzi w komplet narzędzi niezbędnych do funkcjonowania w zmieniającym się świecie. Tym staranniej należy zrewidować zadania szkolnej humanistyki, ponieważ jest to ten obszar, który w znacznej mierze odpowiada za wspieranie kształcenia uniwersalnych postaw i wartości młodych ludzi. Martha Nussbaum w głośnym tekście Nie dla zysku trafnie diagnozuje sytuację, przed którą stanęliśmy jako społeczeństwa świata:

Gorączka dochodowości panująca na globalnych rynkach grozi zagubieniem wartości cennych dla przyszłości demokracji, szczególnie w czasach religijnych i gospodarczych turbulencji. (...)

Orientacja na zysk sprawia, że wielu zaniepokojonych przywódców właśnie nauki ścisłe i technologię uznaje za decydujące o przyszłości państw. (...) Martwi mnie tylko, że inne umiejętności, równie ważne, mogą się zagubić w tej nastawionej na konkurencję krzątaninie. (...)

Te umiejętności są ściśle związane z dyscyplinami humanistycznymi i artystycznymi: zdolność do krytycznego myślenia i wykroczenia poza więzy lokalne i spojrzenia na globalne problemy z perspektywy „obywatela świata”, wreszcie zdolność do współczucia i zrozumienia trudnej sytuacji drugiej osoby (Nussbaum 2016, 22-23).

W tej konkluzji, jakkolwiek przekonywającej, podkreśla się rolę indywidualnego rozwoju młodego człowieka jako kogoś, kto jest gotowy przekraczać własne granice, dostrzegać innych, rozumieć ich, a nawet im współczuć. Rzecz jasna, takiej postawie etycznej nie można niczego zarzucić, nie pozwala ona jednak w pełni przekroczyć zaklętego kręgu „liberalnego błędu" - punktem odniesienia edukacji wciąż pozostaje jednostka i na jakości kształcenia indywidualnego opiera możliwość przetrwania demokracji.

Pozostanie na poziomie indywidualistycznym w myśleniu o szkole i kształceniu humanistycznym w mojej ocenie nie wystarczy do tego, by skutecznie „pomyśleć szkołę na nowo”. Rozwój społeczny można projektować tylko w odniesieniu do wspólnoty, bo indywidualny system aksjologiczny, poznawczy i etyczny winien być stale weryfikowany w odpowiedzi na wartości wspólne. W tym kontekście można podkreślić rolę szkoły jako przestrzeni indywiduacji i dojrzewania do bycia w społeczeństwie, zarówno w perspektywie osobistej i jednostkowej, jak i wspólnotowej. Podobną myśl odnaleźć można w tekstach Bernarda Stieglera, dotyczących refleksji nad edukacją, a ściślej nad rozwojem umiejętności rozumnego oglądu rzeczywistości [Aufklärung]:

Aufklärung (...) nie jest bezosobową możnością; jest to możliwość noetyczna drzemiąca w każdej z nas i w tym względzie - jako możność dzielona przez wszystkich, których należy zaktualizować - konstytuuje odpowiedzialność będącą stale czymś jednostkowym i zarazem kolektywnym. O ile nie wszyscy jesteśmy rozumni w działaniu [acte], o tyle wszyscy jesteśmy rozumni w możności (Stiegler 2017, 52). 
Spojrzenie na edukację humanistyczną jako na przestrzeń dobrze pomyślanej zbiorowej i jednostkowej indywiduacji kieruje mnie w stronę kolejnego pojęcia, które nabiera jeszcze większego znaczenia w sytuacji kryzysu społecznego. Jest to pojęcie upodmiotowienia - dla mnie ważniejsze niż współczucie wobec drugiego. Oznacza stopniowe przekazywanie odpowiedzialności za własny rozwój uczniom przez uczenie ich strategii wspierających nabywanie kompetencji przy jednoczesnej głębokiej i empatycznej świadomości ich specyficznych potrzeb (społecznych, kulturowych, poznawczych). Upodmiotowienie wymaga postawy proaktywnej zarówno od uczniów, jak i nauczycieli, ale jego specyfiką jest planowanie wyprzedzające - taki wybór celów kształcenia, które w najlepszy i najbardziej efektywny sposób przygotują młodych ludzi do funkcjonowania w społeczeństwie. Wspólnota społeczna czy szkolna zbudowana na jego podstawie oznacza odwołanie do wartości prawa do podmiotowości dla każdego jej członka.

Przekazywanie odpowiedzialności za uczenie się wymaga od szkoły systematycznego, zaplanowanego i widocznego kształtowania u uczniów autonomiczności poznawczej, rozumianej jako postawa gotowości do zachowania własnego, dobrze przemyślanego i popartego dowodami stanowiska. Wiąże się ona ściśle z pojęciem krytycznego myślenia, czyli procesem intelektualnym (myślenie ewaluacyjne, racjonalne i logiczne) i postawą etyczną (dążeniem do prawdy jako celem nadrzędnym działań intelektualnych) oraz w sferze umiejętności - argumentowaniem, prezentowaniem i uzasadnianiem własnych wniosków (za: Wasilewska-Kamińska 2016). Nauczanie zdalne ujawniło, że jedną z największych bolączek polskich uczniów była nieumiejętność samodzielnego uczenia się, co można rozumieć jako brak autonomiczności poznawczej właśnie. Sądzę, że warto w tym miejscu zwrócić uwage na potrzebę kształcenia kompetencji metapoznawczych, które są podstawowym warunkiem efektywnego uczenia się. Jest to obszar, który w polonistycznej praktyce dydaktycznej wciąż nie jest uznawany za priorytetowy, szczególnie w aspekcie uczenia rozumienia czytanych tekstów. Wszystkie te umiejętności, pod warunkiem regularnego i dobrze zaplanowanego wdrażania w praktyce szkolnej, mają szansę stać się narzędziami upodmiotowienia.

Takie zmiany mogłyby być wdrażane na poziomie podstaw programowych dla różnych przedmiotów, ale chyba kluczowe w tym kontekście wydaje się wnikliwe i wielowymiarowe przekształcenie zadań szkoły oraz warunków i sposobów ich realizacji. Dotychczasowe reformy programowe pokazały dobitnie, że wyznaczenie (nawet bardzo szczegółowe, jak ma to miejsce w najnowszej podstawie) celów i treści kształcenia w niewielkim tylko stopniu wpływa na zmianę praktyki nauczycielskiej. Do tego potrzeba przede wszystkim zmiany postaw indywidualnych nauczycieli, przede wszystkim gotowości na elastyczne reagowanie na zmiany społeczne. 


\section{Cele edukacji polonistycznej - krok na drodze ewolucji}

W poprzednich fragmentach tekstu skupiałam się w myśleniu o zadaniach współczesnej edukacji na perspektywie dalekiej i ogólnej. Ich realizacja wymaga rozwiązań systemowych, na poziomie świadomie konstruowanej polityki edukacyjnej, których wprowadzenia winniśmy wymagać od odpowiedzialnych za nie osób. W mojej ocenie nie zdejmuje to jednak z nauczycieli i nauczycielek odpowiedzialności za jakość procesu dydaktycznego, jaki prowadzą w swoich klasach. Dogłębne zrozumienie mechanizmów i procesów kształtujących rzeczywistość, a następnie zastosowanie tej wiedzy w praktyce na wszystkich poziomach działalności szkoły, powinno być w mojej ocenie jednym z priorytetów planowania dydaktycznego w obecnej sytuacji. Pojedynczy nauczyciel ma nikły wpływ na całość systemu, jednak jestem przekonana, że nawet najdrobniejsza zmiana w praktyce nauczycielskiej, oparta na dobrze pomyślanej diagnozie i wywiedziona z przekonania o wartości odpowiedzialności społecznej szkoły, ma szansę wywołać edukacyjny „efekt motyla”. Takim działaniem jest kształcenie krytycznego odbioru tekstów.

W dobie zalewu informacji umiejętność krytycznej ewaluacji, weryfikowania i oceniania ich wiarygodności wydaje się kluczowa. Jednak w szkole opartej na podmiotowości uczniów wymaga to stopniowego przekonywania ich o tym, że są wystarczająco kompetentni, by podjąć dyskusję z tekstem i jego autorem, nazywać intencje wyrażone wprost lub niejawne, a także budować świadomość wpływu, jaki teksty wywierają na świat i społeczeństwo. W toku nauki szkolnej uczniowie stają się gotowi na samodzielne działanie w rzeczywistości tekstów, która narzuca odbiorcom trwanie w „przymusie interpretacji” - wciąż na nowo mierzą się z tym, co niejasne i wymaga głębokiej refleksji. Dzięki dobremu przygotowaniu mają szansę nie pozostać bezradnymi wobec niej. Jest to jedna z podstawowych wartości wypływających z pracy na lekcjach języka polskiego, a takie przekonanie może przekładać się na działania sprzyjające rozwijaniu podmiotowości i autonomiczności poznawczej uczniów.

Wsparciem w planowaniu działań lekcyjnych dla uczniów może być, zmodyfikowana i dostosowana do potrzeb polskich uczniów, stosowana w szkołach amerykańskich procedura czytania oparta na internalizowaniu kolejnych etapów pracy z tekstem przez ich wielokrotne powtarzanie. $\mathrm{W}$ praktyce oznacza to, że poznawanie procedur postępowania $\mathrm{z}$ tekstem jest równie ważnym celem dydaktycznym, co samo poznawanie, analizowanie i interpretowanie tekstu. W czytaniu proceduralnym kładzie się nacisk na kształcenie nawyku uważnego czytania (wielokrotna lektura tego samego tekstu w kolejności od szczegółu do ogółu lub od konkretu do abstrakcji) i częstego notowania (utrwalanie refleksji i odnoszenie się do zmian w sposobie myślenia), stopniowanie trudności przez dzielenie pracy na etapy, a także interakcje między uczniami (rozmowy w parach, wymiany 
doświadczeń). Wspiera się także kształcenie refleksji metapoznawczej przez częste odwoływanie się do samej procedury i analizowanie wyników pracy. Amerykańscy dydaktycy podkreślają także wagę skupienia na tekście oraz rozumienia jego struktury (Beers, Probst 2012). Działania te odnoszą się tzw. praktyk o udowodnionej skuteczności [High Impact Practices], które wymienione są w dużym badaniu-metaanalizie przygotowanej przez powołany w 1997 roku przez Kongres USA National Reading Panel, w którym mierzono efektywność strategii za pomocą porównania wyników standaryzowanych testów biegłości czytania (por. NRP, 2000) ${ }^{1}$.

Warto odnieść się także do wskazanych przez Roberta J. Marzano i Johna Hattiego skutecznych metod i strategii nauczania. To, co obaj badacze wyróżniają jako konieczne elementy procesu, mające podstawowe znaczenie dla jego skuteczności, to: wyznaczanie i komunikowanie celów nauczania, monitorowanie i komunikowanie efektów nauczania (w tym informacja zwrotna) i stawianie uczniom wyzwań, co wiąże się z projektowaniem zadań edukacyjnych z wyższych poziomów taksonomicznych (por. Marzano 2012 oraz Hattie 2015). Działania takie maja odbicie w omawianiu na lekcjach tekstów wymagających głębszej refleksji i złożonego rozumowania, omawiających aktualne problemy.

Jestem pewna, że takie zmiany w praktyce nauczycielskiej, które nie wypływają z wielkich, systemowych zmian programowych, mogą odnieść rzeczywisty skutek i doprowadzić w konsekwencji do lepszego i bardziej świadomego kreślenia założeń polityki edukacyjnej na różnych poziomach.

\section{Przykład projektu lekcji}

Komentarz dydaktyczny: Zgodnie z postulatami wyrażonymi wcześniej, dotyczącymi wysokich wymagań poznawczych, do pracy lekcyjnej wybrałam tekst, który choć nie jest skomplikowany w warstwie językowej, odnosi się do złożonego problemu odpowiedzialności za przyszłość świata. Jest to fragment jednego z esejów Andriego Snæra Magnasona, Rozmowa o przyszłości, z tomu $O$ czasie i wodzie. Fragment ten znajduje się w aneksie do niniejszego artykułu. Wydaje mi się, że jest to tekst odpowiedni do pracy w klasach VII-VIII szkoły podstawowej.

Cel ogólny lekcji: Uczeń / uczennica krytycznie czyta teksty

Cel szczegółowy lekcji: Uczeń / uczennica problematyzuje tekst i odnosi go do własnego doświadczenia

Czas trwania lekcji: 90 minut

Przebieg lekcji

Etap I - przygotowanie do pracy z tekstem w formie minilekcji (krótkiego wykładu), maksymalnie 8-10 minut.

\footnotetext{
${ }^{1}$ Siedem wskazanych w badaniu strategii to: monitorowanie rozumienia, wzajemne uczenie się, używanie wizualizacji, odpowiadanie na pytania do tekstu, ćwiczenia w generowaniu pytań do tekstu, analizowanie struktury tekstu oraz streszczanie.
} 
Nauczyciel/ -ka wprowadza uczniów do lekcji, pokazując zdjęcia rodzinne z różnych okresów. Po obejrzeniu zdjęć nauczyciel/-ka pyta: Przez minute pomyślcie, jakie emocje i skojarzenia budza $w$ was te zdjęcia. Po minucie proszę osoby chętne o podzielenie się z nami. Po odsłuchaniu chętnych do wypowiedzenia się uczniów na temat emocji i skojarzeń nauczyciel/ -ka wyjaśnia:

Zanim zaczniemy, przypomnijmy zasady pracy z tekstem (zasady mogą być zaprezentowane w formie wizualnej, na przykład plakatu): ćwiczymy uważność - szukamy ważnych szczegółów; czytamy tekst wielokrotnie; notujemy; dzielimy się z innymi. Uczniowie otrzymują kopie tekstów. To ważne, by każdy miał swój egzemplarz, bo będą mogli na nich notować.

Dzisiaj będziemy się zastanawiać nad tym, jakie znaczenia ma dla nas czas. Przeczytamy krótki tekst Andriego Snœra Magnasona Rozmowa o przyszłości, $w$ którym autor zaprosi nas do jadalni $w$ domu swojej babci i do rozmowy o czasie. Posłuchajcie uważnie.

Etap II - pierwsza lektura tekstu i wyszukiwanie szczegółów, 10 minut.

Nauczyciel/ -ka czyta tekst na głos. W tej metodzie to bardzo ważny element, związany z włączaniem wszystkich uczniów, nawet tych, którzy mają trudność w czytaniu, do lekcji od samego jej początku.

Następnie prosi, aby każdy raz jeszcze przeczytał tekst w ciszy, podkreślając w nim wszystkie fragmenty dotyczące dat. Następnie zachęca do powiązania ich z wydarzeniami, do których się odnoszą. Czytamy przez soczewki, dzisiaj użyjemy soczewki czasu. Jakie daty wymienione sq $w$ tekście? Z jakimi wydarzeniami się łączą?

Uczniowie pracują indywidualnie. W parach mogą porównać swoje zaznaczenia. Nauczyciel/ -ka monitoruje pracę uczniów.

Etap III - łączenie informacji i wnioskowanie, 15 minut.

Nauczyciel/-ka dzieli klasę losowo na zespoły trzyosobowe. Na podstawie notatek na tekście uczniowie odpowiadają na pytania i notują odpowiedzi: Jakie znaczenie dla autora ma czas? Jak sqdzicie, dlaczego w tekście pojawia się tyle dat-jakie one maja. znaczenie dla nas jako czytelników? Nauczyciel/ -ka monitoruje pracę zespołów.

Kiedy każdy uczeń ma już gotową notatkę, nauczyciel/ -ka prosi: Wybierzcie z tekstu jedno zdanie na temat czasu, które uważacie za najważniejsze. Wyjaśnijcie swoim zespołom, dlaczego tak uważacie. Wybierzcie jedno wspólne zdanie dla zespołu. Przedstawicie je na forum wraz z uzasadnieniem.

Etap IV - poszerzanie perspektywy osobistej, 10 minut.

Nauczyciel/-ka przedstawia uczniom zadanie do pracy indywidualnej. Na tym etapie najważniejsza myśl tekstu jest omówiona, a kolejne działania wprowadzają osobistą perspektywę uczniów. Ważne jest także ponowne omówienie całej procedury czytania, kolejnych kroków i refleksji.

Wyobraź sobie, że teraz siedzisz przy kuchennym stole z najstarszym członkiem Twojej rodziny.

- Ile ten ktoś ma lat?

- W którym roku Ty skończysz tyle samo lat?

- W którym roku Twój wnuk lub Twoja wnuczka skończy tyle samo lat?

- Jaki czas Ty spajasz?

Nauczyciel/-ka, po wysłuchaniu uczniów, może zaprezentować swoje wyliczenia.

Polonistyka. Innowacje

Numer 12, 2020 
Etap V - wykorzystanie do działania, 45 minut.

Kolejny etap pracy to czas na samodzielną pracę uczniów, może być zorganizowana jako praca indywidualna lub zespołowa. Uczniowie wyszukują w dostępnych źródłach (na przykład strony internetowe https://www.newscientist.com/round -up/world-2076/, lub https://www.crazynauka.pl/bedzie-swiat-30-przewidywanianaprawde-moga-sie-spelnic) informacje na temat przewidywanych zmianach globalnych w następnych 50-100 latach. Następnie przygotowują się do napisania tekstu pt. Jaki mogę mieć wpływ na czas, który spajam? Ważne, by zadbać o publiczną prezentację tych prac (w formie pisemnej lub ustnej), tak aby wszyscy uczniowie mogli się z nimi zapoznać.

\section{Zakończenie - quo vadis, szkoło?}

Tekst Magnasona skłania mnie do wyliczenia, jaki czas spajam jako nauczycielka. Decyzje podejmowane dziś mogą mieć wpływ nawet na kolejne dwa pokolenia dzieci, które z kolei w przyszłości budować będą rzeczywistość społeczna i polityczną. To, kto będzie miał poczucie sprawstwa, a kto - bierności, zależy od jakości edukacji.

Efektywność edukacji zależy od tego, w jaki sposób kształtuje się całość polityki edukacyjnej (na poziomie zadań samorządów, dokumentów oświatowych, nadzoru pedagogicznego i wielu innych elementów), dlatego nie wolno zaprzestać podejmowania prób wpływania na jej kształt. To jednak nie znaczy, że działania nauczycieli w klasie nie mają znaczenia. Z jednej strony, poszczególne pomysły zwiększające efektywność nie mogą być oderwane od mądrze zaplanowanego systemu. Z drugiej - ignorowanie znaczenia szczegółów negatywnie wpływa na realizację całości.

Dopóki działania podejmowane w szkole i dla szkoły będą doraźną, krótkotrwałą reakcją na bieżące problemy, kryzys będzie się przedłużał. Obecna sytuacja mogłaby być inspiracją dla dalekosiężnych zmian i miejmy nadzieję, że tak właśnie będzie.

\section{Bibliografia}

Archacka Magdalena, 2016, Szkoła. Społeczna rola heterotopii, w: Gromysz J., Włodarczyk R. (red.), Utopia a edukacja, t. I, Wrocław.

Beers Kylene, Probst Robert E., 2012, Notice \& Note: Strategies for Close Reading, Portsmouth, NH: Heinemann.

Bendyk Edwin, 2020, W Polsce, czyli wszędzie. Rzecz o upadku i przyszłości świata, Warszawa.

Foucault Michel, 2005, Inne przestrzenie, Rejniak-Majewska A. (przeł.), „Teksty Drugie", nr 6/2005, s. 117-125.

Harari Noah, 2018. Homo deus. Krótka historia jutra, Romanek M. (przeł.), Warszawa.

Hattie John, 2015, Widoczne uczenie się dla nauczycieli, Janowska Z. (przeł.), Warszawa. 
Marzano Robert J., 2012, Sztuka i teoria skutecznego nauczania, Kasprzak A., Czernik J., Kurzemska A. (przeł.), Warszawa.

Nussbaum Martha C., 2016, Nie dla zysku: dlaczego demokracja potrzebuje humanistów, Pawłowski Ł. (przeł.), Warszawa.

Stiegler Bernard, 2017, Wstrzasy. Głupota i wiedza XXI wieku, Krzykawski M. (przeł.), Warszawa.

Wasilewska-Kamińska Ewa, 2016, Myślenie krytyczne jako cel kształcenia, Warszawa.

\section{Prace badawcze}

Blanchet Thomas, Chancel Lucas, Gethin Amory, 2019, How Unequal Is Europe? Evidence from Distributional National Accounts, 1980-2017, „WID.world Working Paper", nr 2019/06, https://wid.world/document/bcg2019-full-paper (dostęp: 06.06.2020).

Bukowski Pawel, Novokmet Filip, 2017, Inequality in Poland: Estimating the whole distribution by g-percentile, 1983-2015, "WID.world Working Paper", nr 2017/21, https://wid.world/document/bukowski-novokmet-poland-1983-2015-wid-world-working-paper-2017-21 (dostęp: 06.06.2020).

Dorn Emma, Hancock Bryan, Sarakatsannis Jimmy, Viruleg Ellen, 2020, COVID19 and student learning in the United States: The hurt could last a lifetime, McKinsey \& Company, https://www.mckinsey.com/industries/public-and-social-sector/our-insights/covid-19-and-student-learning-in-the-united-states-the-hurt-could-last-a-lifetime (dostęp: 25.07.2020).

Dyrektorzy do zadań specjalnych - edukacja zdalna w czasach izolacji. Prezentacja wyników badania, 2020, Sobiesiak-Penszko P., Pazderski F., https://lekcjaenter.pl/strona/28/raport-\%22dyrektorzy-do-zadan-specjalnych---edukacja-zdalna-w-czasach-izolacji\%22 (dostęp: 25.07.2020).

National Reading Panel. Teaching Children to Read: An Evidence-based Assessment of the Scientific Research Literature on Reading and Its Implications for Reading Instruction. Reports of the Subgroups, 2000, Washington, DC.

Sitek Michał, Ostrowska Barbara (red.), 2020, PISA 2018. Czytanie, rozumienie, rozumowanie, Warszawa.

Uczenie (się) w czasach epidemii, trzyetapowe badanie postaw nauczycieli pod kierunkiem B. Walczaka i M. Wąsowskiej, Szkoła Edukacji (marzec-czerwiec 2020), raport w trakcie publikacji.

\section{Aneks}

\section{Andri Snær Magnason, Rozmowa o przyszłości [fragment]}

Jestem u babci Huldy i dziadka Árniego w Hlaðbær, siedzimy w kuchni, nieopodal domu wiją się meandry rzeki Elliðaár (...) Otwieram laptop, odpalam klip i pokazuję babci i mamie film, którego od dziesięcioleci nikt nie oglądał. (...) To film, który dziadek nakręcił w 1956 roku, czarno-biały i niemy, ale jakość obrazu jest wciąż doskonała. Odświętnie ubrane dzieci siedzą w jadalni w wielkim białym domu przy Selás 3, który pradziadek 
pobudował nad rzeką. Przed dziećmi stoją małe szklane buteleczki coli, zjawia się babcia z okazałym tortem śmietanowym przystrojonym zapalonymi świeczkami. U szczytu stołu zajęły miejsca dziesięcioletnie bliźniaczki, siedzą ramie w ramię, wybuchają śmiechem i ile sił w płucach dmą w świeczki. (...) To niesamowite, że szesnastomilimetrowa taśma $\mathrm{z}$ urodzinami dzieci z 1956 roku przetrwała. Z tamtego okresu nie zachowały się nawet filmy przedstawiające członków rządów Islandii.

I znów jesteśmy w roku 2018, siedzimy w tej samej kuchni, tylko sześćdziesiąt lat później. Mama przekroczyła siedemdziesiątkę, babcia ma dziewięćdziesiąt cztery lata, a moja najmłodsza córeczka dziesięć. (...)

Proszę moją młodszą córkę Huldę Filipię, by coś dla mnie przeliczyła:

- Ile twoja babcia ma lat, jeśli urodziła się w roku 1924?

- Dziewięćdziesiąt cztery - odpowiada natychmiast. (...)

- Ale teraz będziesz się musiała przyłożyć. W którym roku ty będziesz miała dziewięćdziesiąt cztery lata? (...)

- W 2102?

- Tak i mam nadzieję, że będziesz równie żwawa, co babcia dzisiaj. Może nawet będziesz mieszkała $\mathrm{w}$ tym domu? I może przyjdzie do ciebie w odwiedziny twoja dziesięcioletnia prawnuczka, usiądzie w tej kuchni w 2102 roku. (...) A spróbujmy jeszcze coś wyliczyć. Kiedy twoja prawnuczka skończy dziewięćdziesiąt cztery lata?

- 2092 plus 94 to razem ... 2186!

Wybucha śmiechem na samą myśl. (...)

- Mam jeszcze jedno zadanie. Ile czasu upłynie od 1924 do 2186 roku? Hulda znów liczy.

- 262 lata?

Wyobraź to sobie. To czas, który spajasz. Znasz ludzi, którzy łączą te lata. Twój czas to czas ludzi, których znasz, kochasz, którzy cię kształtują. Ale twój czas to też czas kogoś, kogo poznasz i pokochasz, czas, który ukształtujesz. Możesz go niemal dotknąć - 262 lata! Babcia przekazuje wiedzę tobie, ty przekazujesz ją swojej prawnuczce. Możesz mieć bezpośredni wpływ aż do 2186 roku.

2186 !

Magnason A.S., Rozmowa o przyszłości, w: O czasie i wodzie, 2020, Godek J. (przeł.), Kraków.

\section{O Autorce}

Kinga Białek - polonistka i hebraistka, absolwentka Uniwersytetu Warszawskiego, z pracą w szkole związana od 2007 roku. Jako współpracowniczka IBE i CKE miała okazję uczestniczyć w zespołach projektowych związanych z badaniami edukacyjnymi na poziomie krajowym (m.in. badania SSM, K3) oraz międzynarodowym (PISA, PIRLS). Od 2015 roku pracuje w Szkole Edukacji PAFW i UW jako dydaktyczka i tutorka. Pracę 
Zadania polonistów w szkole pomyślanej na nowo. Jak uczyć uczenia się

doktorską Kształcenie umiejętności odbiorczych uczniów w wieku 13-15 lat $w$ odniesieniu do tekstów argumentacyjnych napisaną pod kierunkiem prof. Krzysztofa Biedrzyckiego obroniła na Wydziale Polonistyki Uniwersytetu Jagiellońskiego. Interesuje ją wszystko, co jest związane z dydaktyką języka polskiego, z uczniami, z nowoczesną, efektywną i wartościową edukacją.

Polonistyka. Innowacje 
